\title{
Article \\ Toluene Bioremediation by Using Geotextile-Layered Permeable Reactive Barriers (PRBs)
}

\author{
Cevat Yaman ${ }^{1, *(D)}$, Ismail Anil ${ }^{1}{ }^{(\mathbb{D}}$, Omar Alagha ${ }^{1}$ (D), Nawaf I. Blaisi ${ }^{1}$, Ayse Burcu Yaman ${ }^{1}$, Aleem Qureshi ${ }^{1}$, \\ Emre Cevik $^{2}$, Suriya Rehman ${ }^{3}{ }^{\mathbb{D}}$, Seyda Tugba Gunday ${ }^{4}$ and Mohammad Barghouthi ${ }^{1}$
}

Citation: Yaman, C.; Anil, I.; Alagha, O.; Blaisi, N.I.; Yaman, A.B.; Qureshi, A.; Cevik, E.; Rehman, S.; Gunday, S.T.; Barghouthi, M. Toluene Bioremediation by Using Geotextile-Layered Permeable Reactive Barriers (PRBs). Processes 2021, 9, 906. https://doi.org/ $10.3390 /$ pr9060906

Academic Editors:

Jacek Antonkiewicz and Beata Rutkowska

Received: 2 May 2021

Accepted: 19 May 2021

Published: 21 May 2021

Publisher's Note: MDPI stays neutral with regard to jurisdictional claims in published maps and institutional affiliations.

Copyright: (c) 2021 by the authors. Licensee MDPI, Basel, Switzerland. This article is an open access article distributed under the terms and conditions of the Creative Commons Attribution (CC BY) license (https:// creativecommons.org/licenses/by/ $4.0 /)$
1 Department of Environmental Engineering, College of Engineering, Imam Abdulrahman Bin Faisal University, Dammam 34212, Saudi Arabia; ianil@iau.edu.sa (I.A.); oaga@iau.edu.sa (O.A.); niblaisi@iau.edu.sa (N.I.B.); abyaman@iau.edu.sa (A.B.Y.); aqureshi@iau.edu.sa (A.Q.); mhbaghouthi@iau.edu.sa (M.B.)

2 Department of Genetics Research, Institute for Research and Medical Consultations (IRMC), Imam Abdulrahman Bin Faisal University, Dammam 34212, Saudi Arabia; ecevik@iau.edu.sa

3 Department of Epidemic Disease Research, Institute for Research and Medical Consultations (IRMC), Imam Abdulrahman Bin Faisal University, Dammam 34212, Saudi Arabia; surrehman@iau.edu.sa

4 Department of Biophysics, Institute for Research and Medical Consultations (IRMC), Imam Abdulrahman Bin Faisal University, Dammam 34212, Saudi Arabia; stgunday@iau.edu.sa

* Correspondence: cyaman@iau.edu.sa

Abstract: Sources of contamination in a subsurface environment are petrol, diesel fuel, gasoline at oil refineries, underground storage tanks, transmission pipelines, and different industries. The permeable reactive barrier (PRB) is a promising technology to remediate groundwater in-situ. In this study, synthetic groundwater samples containing toluene are treated in three reactor columns by biological processes. PRB-1 consisted of sand and gravel as reactor media, microbial inoculum (bioaugmentation-BA), and nutrients (biostimulation-BS); PRB-2 consisted of sand and gravel as reactor media, microbial inoculum, nutrients, and 12 layers of nonwoven geotextile fabrics; and PRB-3 consisted of only sand and gravel as reactor media (natural attenuation-NA). This study was conducted to assess the impact of geotextile fabric filter, bioaugmentation, and biostimulation on toluene degradation efficiency. After 167 days of treatment, toluene biodegradation efficiencies varied between $88.2 \%$ and $93.8 \%$ for PRB 1 , between $98.0 \%$ and $99.3 \%$ for PRB 2 , and between $14.2 \%$ and $68.6 \%$ for PRB 3 . The effluent toluene concentrations for PRB-2 were less than the guideline value $(0.7 \mathrm{mg} / \mathrm{L})$ of the World Health Organization. Reaction rate data were fitted with a first-order kinetic reaction rate model. This study showed that the toluene removal efficiency in the geotextile layered PRB combined with BA and BS process was significantly higher compared to the other processes tested. This lab-scale study introduced a new PRB configuration suitable for the remediation of sites contaminated with toluene.

Keywords: permeable reactive barrier; toluene; bioremediation; biostimulation; bioaugmentation; natural attenuation; groundwater; first-order reaction kinetics

\section{Introduction}

One of the most commonly used technologies for in-situ groundwater treatment is permeable reactive barriers (PRBs). PRBs are filled with reactive materials which must be more permeable than the surrounding aquifer material. When compared to conventional pump and treat systems, the PRB method is much cheaper because there is no continuous energy input needed. The other benefit of PRBs is that replacement of the PRB material is always possible [1]. There are two types of PRBs, continuous PRBs and funnel and gate system PRBs. Continuous PRBs consist of a single reactive zone, whereas funnel and gate PRBs consist of permeable gate (reactive zone) placed between two impermeable walls that direct the contaminated plume towards the reactive zone. The mechanisms of interaction in PRBs are degradation, precipitation, and sorption. The types of reactive 
materials used in PRBs serve different purposes: Some change $\mathrm{pH}$ or redox potential, other cause precipitation, some PRB materials have high sorption capacity, and some release nutrients and oxygen to enhance degradation. Reactive materials used in PRBs include activated carbon (AC), Al, ferric oxide, peat, zeolite, lignite, zero valent metals, fly ash, lime, limestone, sand, and clay.

PRBs consisting of zero valent iron (ZVI) can also be used to treat groundwater contaminated with chlorinated solvents, nitrate, chromium, uranium, and pesticides [2]. In one study, PRB columns filled with olive nuts, sand, and soil were effectively used to treat wastewater containing nitrate [3]. Polyaromatic hydrocarbons (PAHs) were successfully removed from water by using PRB materials of wheat straw and coconut shell [4]. Corn straw, fly ash, Fe-Mn, and zeolite were used as PRB materials to reduce the concentrations of $\mathrm{Pb}$ and $\mathrm{Cd}$ from groundwater [5]. Steel manufacturing basic oxygen furnace sludge (BOFS) was tested as a PRB material to remove $\mathrm{Cr}^{+6}$ from soil [6]. Two lab-scale column studies used ZVI and ZVI + zeolite to treat leachate [7]. In one study, ZVI, zeolite and activated carbon were used as PRB materials to treat groundwater [8].

Toluene, one of the BTEX (benzene, toluene, ethylbenzene, and xylene) compounds, is a clear, colorless liquid that becomes vapor when exposed to air at room temperature. It has a water solubility of $515 \mathrm{mg} / \mathrm{L}$ and a vapor pressure of $22 \mathrm{mmHg}$ at $20^{\circ} \mathrm{C}$. Toluene is typically used in a mixture with chemicals such as other solvents and paint pigments. Products that contain toluene, such as paints, metal cleaners, and adhesives, are used in many industries. Gasoline and other fuels also contain toluene. Hydrocarbons can be mobilized as a non-aqueous liquid phase (NALP) until they reach the capillary fringes, under the influence of gravity and capillary forces $[9,10]$. NALP in the form of residual contamination can be a constant source of groundwater pollution. The interaction of the retained hydrocarbon with water allows its components to partially dissolve, especially a group of aromatic organic chemical compounds such as toluene [11]. The dissolved phase is highly mobile and is responsible for transporting contaminant over long distances from the source of contamination [12,13].

Microorganisms responsible for degrading petroleum products are defined as either eukaryotic or prokaryotic organisms. Various research studies have been conducted on biodegradation of petroleum derived hydrocarbons by microorganisms [14,15]. Some of the microorganisms that are effective on biodegradation of petroleum hydrocarbons are bacteria from genera Pseudomonas, Acinetobacter, Flavobacterium, Achromobacter, Rhodococcus, Mycobacterium, Bacillus, Alcaligenes, Aspergillus, Mucor, Penicillium, and Candida. The objective of this study was to investigate the effect of the biomass holding capacity of geotextile fabrics and biostimulation/bioaugmentation processes on toluene biodegradation efficiency in a freshly contaminated water. Three different phases were studied: Phase 1 at $5 \mathrm{mg} / \mathrm{L}$ of influent toluene concentration, phase 2 at $15 \mathrm{mg} / \mathrm{L}$, and phase 3 at $25 \mathrm{mg} / \mathrm{L}$. The term biostimulation is used to describe the addition of essential electron acceptors such as nutrients to enhance microbial growth. The term bioaugmentation is used to describe the addition of essential microorganisms.

\section{Materials and Methods}

For each process studied, experimental analysis included 3 replicates and each experiment was repeated 3 times.

\subsection{PRB Filling Material Preparation}

Sand and gravel mixture in different sizes was selected as the filling material of the PRBs. The physical characteristics of the filling material are presented in Table 1. Filling materials were initially washed thoroughly with distilled water to remove impurities before placing them in the PRB reactors. 
Table 1. Properties of filling material used in permeable reactive barriers (PRBs).

\begin{tabular}{ccccccc}
\hline Material & $\begin{array}{c}\text { Average } \\
\text { Diameter (mm) }\end{array}$ & $\begin{array}{c}\text { \% of } \\
\mathbf{S i O}_{\mathbf{2}}\end{array}$ & $\begin{array}{c}\text { \% of Material } \\
\text { in PRBs }\end{array}$ & $\begin{array}{c}\text { \% of Acid } \\
\text { Solubility }\end{array}$ & Bulk Density $\left(\mathbf{t} / \mathbf{m}^{\mathbf{3}}\right)$ & Specific Gravity $^{\text {Siam }}$ \\
\hline Silica sand & $1-2$ & $98 \pm 1$ & $25 \%$ & $1 \pm 0.5$ & $1.5-1.70$ & $2.55-2.70$ \\
Silica sand & $2-3$ & $98 \pm 1$ & $25 \%$ & $1 \pm 0.5$ & $1.5-1.70$ & $2.55-2.70$ \\
Silica sand & $3-6$ & $90 \pm 1$ & $25 \%$ & $10 \pm 0.5$ & $1.5-1.70$ & $2.55-2.70$ \\
Silica gravel & $8-12$ & $90 \pm 1$ & $25 \%$ & $10 \pm 0.5$ & $1.5-1.70$ & $2.55-2.70$ \\
\hline
\end{tabular}

\subsection{Configuration of the PRBs}

Three PRBs (60 cm height and $10 \mathrm{~cm}$ diameter) were filled with gravel and coarseto-medium-sized sand. Each PRB column consisted of an influent tank and an effluent tank, as depicted in Figure 1. The PRB columns were operated as up flow reactors. Reactor 1 (PRB-1) and reactor 2 (PRB-2) were inoculated with specific bacteria (Alcanivorax) and required nutrients (ammonium chloride as $\mathrm{N}$ source and potassium dihydrogen phosphate as P source) were added. To maintain aerobic conditions, influent tank for PRB-1 and PRB-2 were aerated when the dissolved oxygen levels fell below $3 \mathrm{mg} / \mathrm{L}$. PRB-2 also included 12 layers of nonwoven geotextile fabrics placed horizontally at $5 \mathrm{~cm}$ intervals. Reactor 3 (PRB-3) was used as control and contained only sand and gravel mixture without bacteria and nutrient addition. Additionally, aeration was not performed for PRB-3 since it was used as control reactor. Simulated PRB columns were designed and constructed for the remediation of toluene by; bioaugmentation and biostimulation (PRB-1), bioaugmentation and biostimulation by using the potential biomass holding capacity of nonwoven geotextile fabrics (PRB-2), and natural attenuation (PRB-3) (Table 2). PRB columns were made of transparent acrylic glass.

(a)

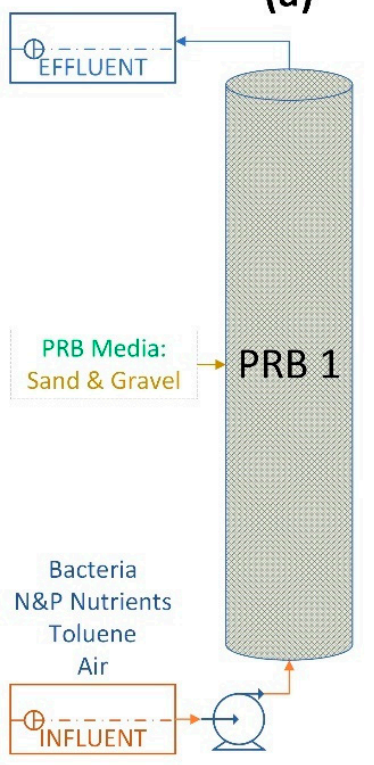

(b)

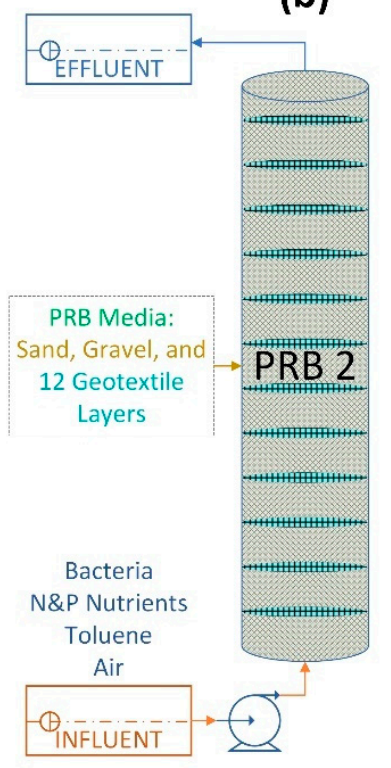

(c)

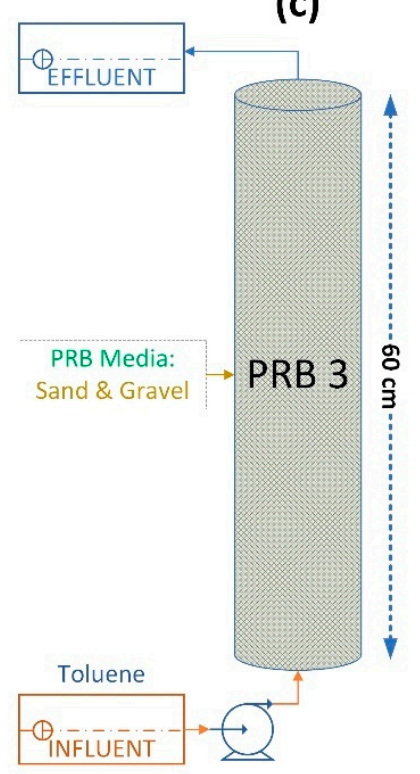

Figure 1. Schematics of PRB columns: (a) Bioaugmentation and biostimulation process (BA + BS), (b) bioaugmentation/biostimulation process and 12 layers of geotextile (BS + BA + Geotextile), (c) natural attenuation process (NA). 
Table 2. Configuration of PRB columns.

\begin{tabular}{ccccc}
\hline Reactors & Geotextile Layers & $\begin{array}{c}\text { Microbial Inoculum } \\
\text { Addition (Bioaugmentation) }\end{array}$ & $\begin{array}{c}\text { Nutrients Addition } \\
\text { (Biostimulation) }\end{array}$ & Toluene Addition \\
\hline PRB-1 (BS + BA) & No & Yes & Yes & Yes \\
PRB-3 (BS + BA + GT) & Yes & Yes & Yes & Yes \\
PRB-3 (NA) & No & No & No & Yes \\
\hline
\end{tabular}

$\mathrm{BS}=$ biostimulation, $\mathrm{BA}=$ bioaugmentation, $\mathrm{GT}=$ geotextile.

\subsection{Loading of the PRB Columns}

After being carefully washed, clean filler materials were evenly mixed in a container and placed in the PRB columns. The filling material for each PRB column included 25\% of silica sand with an average diameter of $1-2 \mathrm{~mm}, 25 \%$ of silica sand with an average diameter of $2-3 \mathrm{~mm}, 25 \%$ of silica sand with an average diameter of $3-6 \mathrm{~mm}$, and $25 \%$ of silica gravel with an average diameter of 8-12 mm. Different than PRB-1 and PRB-3, PRB-2 also contained 12 nonwoven geotextile fabric layers horizontally placed at $5 \mathrm{~cm}$ intervals. Geotextile layers were expected to host and grow toluene biodegrading microorganisms.

\subsection{Pore Volume and Porosity Tests}

Pore volume and porosity tests were performed to determine the volume and volume distribution of pores in PRB columns. In general, both the size and volume of pores affect the performance of the PRB columns. Therefore, the pore volume distribution is useful in understanding PRB performance and determining a material that can be expected to perform in a particular manner. Pore volume and porosity tests were performed before the PRB columns started operating.

\subsection{Flow Rate and Hydraulic Residence Time Tests}

Hydraulic residence time (HRT) ( $t$ ) is a measure of the average time a soluble compound remains in a PRB. In engineering, volumetric flow rate is the volume of fluid passing per unit of time. Flowrate and hydraulic residence times for each PRB were determined prior to the start of operation.

\subsection{Bioaugmentation + Biostimulation (PRB-1 and PRB-2)}

Nutrient requirements for phase $1(5 \mathrm{mg} / \mathrm{L})$, phase $2(15 \mathrm{mg} / \mathrm{L})$, and phase $3(25 \mathrm{mg} / \mathrm{L})$ : Toluene has a molecular weight of $92,91.3 \%$ of which is carbon (C). As nutrient sources, ammonium chloride $\left(\mathrm{NH}_{4} \mathrm{Cl}\right)$ and potassium dihydrogen phosphate $\left(\mathrm{KH}_{2} \mathrm{PO}_{4}\right)$ were used. Selected C:N:P ratios provide a better understanding of decomposition processes and improved modeling of aquatic ecosystems. In general, C:N:P ratio varies from 100:10:1 and 100:5:1 for aerobic process depending upon the type of biological treatment. Using the Droste formula, the ratio of C:N:P required to maintain aerobic bacterial growth will be 100:5:1 [16]. For anaerobic growth, the C:N:P ratio can range from 250:5:1 to 500:5:1 [17]. Based on the selected C:N:P ratio of 100:5:1, nutrient requirements for phase 1, phase 2, and phase 3 are presented in Table 3. Nutrient calculations were based on 5, 15, and $25 \mathrm{mg}$ of toluene dissolved in $1 \mathrm{~L}$ of distilled water.

Table 3. Nutrient, bacteria, and oxygen requirements for phase 1, phase 2, and phase 3 studies.

\begin{tabular}{|c|c|c|c|}
\hline & Phase 1 (5 mg/L) & Phase 2 (15 mg/L) & Phase $3(25 \mathrm{mg} / \mathrm{L})$ \\
\hline $\mathrm{NH}_{4} \mathrm{Cl}(\mathrm{mg})$ & 0.525 & 1.57 & 2.63 \\
\hline $\mathrm{KH}_{2} \mathrm{PO}_{4}(\mathrm{mg})$ & 0.159 & 0.478 & 0.796 \\
\hline Initial dose of bacteria (mg) & 500 & 1500 & 2500 \\
\hline Monthly maintenance dose of bacteria (mg) & 500 & 1500 & 2500 \\
\hline Oxygen requirement (mg) & 15.6 & 46.9 & 78.2 \\
\hline
\end{tabular}


Bacteria requirements for phase 1, phase 2, and phase 3: In toluene bioremediation, microorganisms convert toluene into non-toxic substances such as $\mathrm{CO}_{2}$ and $\mathrm{H}_{2} \mathrm{O}$. Microorganisms break down the molecular structures of toluene using their mass as an energy source. Due to the high degree of interface between bacteria and toluene, the rate of degradation tends to be fast at first, but gradually decreases as more biodegradable toluene is consumed. The microbial inoculum used in this study was manufactured as a combination of naturally occurring species. Microbiological analysis of the inoculum indicated that Alcanivorax was the dominant bacterium [18]. Based on the amounts of toluene and nutrients added to PRB-1 and PRB-2, $0.5 \mathrm{~g}$ of microbial inoculum in powder form was added to $1 \mathrm{~L}$ of distilled water that already contains $5 \mathrm{mg} / \mathrm{L}$ toluene (phase 1 ) and necessary nutrients determined above. Furthermore, the microbial inoculum amounts for $15 \mathrm{mg} / \mathrm{L}$ (phase 2) and $25 \mathrm{mg} / \mathrm{L}$ toluene (phase 3) concentrations were determined as 1.5 and $2.5 \mathrm{~g}$, respectively. Then, monthly maintenance doses in the same amount as the initial inoculum were added to PRB-1 and PRB-2 to maintain the microorganism levels steady (Table 3).

Geotextile fabrics in PRB-2: Twelve layers of nonwoven geotextile fabrics (layer 1 being the first layer at the bottom and layer 12 being the last layer at the top) were horizontally placed at $5 \mathrm{~cm}$ intervals. Geotextile fabrics were expected to host/grow toluene biodegrading bacteria in their interior structure. Properties and locations of geotextile fabrics used in PRB-2 are presented in Table 4.

Table 4. Properties and locations of geotextile fabrics used in PRB-2.

\begin{tabular}{|c|c|c|c|c|c|c|}
\hline $\begin{array}{l}\text { Geotextile } \\
\text { Name }\end{array}$ & $\begin{array}{c}\text { Location in } \\
\text { PRB-2 }\end{array}$ & $\begin{array}{c}\text { Thickness @ } \\
\text { 2kPa (mm) }\end{array}$ & $\begin{array}{c}\text { Apparent } \\
\text { Opening Size } \\
(\text { AOS })(\mu \mathrm{m})\end{array}$ & $\begin{array}{l}\text { Permeability } \\
\qquad(\mathrm{mm} / \mathrm{s})\end{array}$ & Polymer Type & $\begin{array}{l}\text { Production } \\
\text { Method }\end{array}$ \\
\hline GT-1 & Layer 1 and 2 & 1.95 & 116.75 & 115.00 & PP & Needle punch \\
\hline GT-2 & Layer 3 and 4 & 1.91 & 112.38 & 113.11 & PP & Needle punch \\
\hline GT-3 & Layer 5 and 6 & 2.04 & 107.40 & 92.60 & PP & Needle punch \\
\hline GT-4 & Layer 7 and 8 & 1.04 & 101.17 & 96.83 & PP & Aqua jet \\
\hline GT-5 & Layer 9 and 10 & 1.20 & 88.00 & 80.00 & PET & Needle punch \\
\hline GT-6 & Layer 11 and 12 & 1.40 & 84.00 & 60.00 & PET & Needle punch \\
\hline
\end{tabular}

GT = Geotextile, $\mathrm{PP}=$ Polypropylene, $\mathrm{PET}=$ Polyester.

\subsection{Natural Attenuation (PRB-3)}

PRB-3 (NA) was operated as a natural attenuation process for comparison with other tanks; therefore, no nutrients or microbial inoculum was added. However, the influent tank to PRB-3 contained toluene at 5, 15, and $25 \mathrm{mg} / \mathrm{L}$ concentrations. Natural attenuation treatment is defined as a natural process where no specific remediation technology is used for the toluene contaminated water.

\subsection{Oxygen Requirement}

Aeration of the toluene contaminated water serves as a highly effective catalyst to speed up the degradation process. The microbial inoculum used in this study contains facultative strains; thus, they can use either dissolved oxygen (DO) or oxygen releasing compounds (ORC). Intermittent aeration in the influent tank was performed in this study especially when the DO levels fell below $3 \mathrm{mg} / \mathrm{L}$.

Dissolved oxygen requirements for phase 1, phase 2, and phase 3: For toluene $\left(\mathrm{C}_{6} \mathrm{H}_{6}\right)$, the biodegradation reaction will take place as follows:

$$
\mathrm{C}_{7} \mathrm{H}_{8}+9 \mathrm{O}_{2} \rightarrow 7 \mathrm{CO}_{2}+4 \mathrm{H}_{2} \mathrm{O}
$$

As shown in the above reaction, 1 mole of toluene requires 9 moles of oxygen. Considering the initial concentrations of toluene as 5, 15 and $25 \mathrm{mg} / \mathrm{L}$, the amount of oxygen required can be calculated as $0.0156 \mathrm{~g}, 0.0469 \mathrm{~g}$, and $0.0782 \mathrm{~g}$ oxygen, respectively (Table 3). 
The required oxygen was provided by ambient air through aeration for PRB-1 and PRB-2, but PRB-3 was not aerated since it was used as control.

\subsection{Effluent Analysis}

\subsubsection{Toluene Analysis}

Toluene concentrations of the samples were determined using an HPLC-UV system (Thermo Scientific Ultimate 3000, Waltham, MA, USA). The chromatographic separation of toluene was performed on a SunfireTM C18 column $(100 \AA, 5 \mu \mathrm{m}, 4.6 \times 250 \mathrm{~mm})$ at a column temperature of $25^{\circ} \mathrm{C}$. An aliquot of $25 \mu \mathrm{L}$ of the sample was injected into the HPLC-UV system with a flowrate of $1 \mathrm{~mL} / \mathrm{min}$. The mobile phase was methanol/water $(70 / 30)$ on isocratic mode. Toluene separation was achieved at $11 \pm 0.5 \mathrm{~min}$ and $254 \mathrm{~nm}$ of UV wavelength. Standard toluene solutions of $0.25,0.5,1.0,2.5,5.0,10.0,20.0$, and $25.0 \mathrm{mg} / \mathrm{L}$ were prepared in water for method calibration. All chemicals and water used were HPLC grade. Calibration curves were acquired by analyzing calibration standard solutions in triplicate within the linear range of each toluene loading. All samples were analyzed in triplicate and mean values were used in further calculations. The detection limit of the toluene quantification method was computed to be mean of blank results plus three times standard deviation of blank results. Relative standard deviation (\%) of 15 replicate analysis were calculated for toluene standards and samples for obtaining the method precision. The linearity, detection limit, and precision of the toluene method were found to be 0.9991 (R2), $0.1 \mathrm{mg} / \mathrm{L}$, and 1.53 (RSD, \%), respectively, which are in a good agreement with the previously reported toluene determination methods in water using HPLC-UV systems [19-21].

\subsection{2. $\mathrm{pH}, \mathrm{DO}$, and Conductivity Analysis}

For $\mathrm{pH}, \mathrm{DO}$, and conductivity analysis, the Hatch HQ $440 \mathrm{~d}$ probe (Benchtop Dual Input Multi-Parameter) was used.

\subsection{Kinetic Model}

A mass balance in the experimental PRB columns was used to find a kinetic model for degradation of toluene. The kinetic model can be defined as shown in Equation [22]:

$$
-\mathrm{r}=-\frac{\mathrm{dC}}{\mathrm{dt}}=\mathrm{k} \cdot \mathrm{C}^{\mathrm{n}}
$$

where $\mathrm{r}$-reaction rate, $\mathrm{k}$ - biodegradation rate, $\mathrm{C}$ - concentration, $\mathrm{t}$ - time, $\mathrm{n}$-reaction order.

The constants, $k$ and $n$, are found by plotting concentration vs time and determining the best suitable line. The half time $\left(t_{1 / 2}\right)$ can be calculated as follows in Equation $(2)[23,24]$.

$$
t_{1 / 2}=\frac{\ln 2}{k}
$$

\section{Results}

This section summarizes the results of experimental analysis, their interpretation, and the discussions.

\subsection{Results of Hydraulic Tests}

Reactor volume, pore volume, hydraulic conductivity, porosity, flow rate, and hydraulic residence time were calculated for each PRB reactor (Table 5). Hydraulic parameters were determined after filling the PRB columns with the filling material. The falling head hydraulic conductivity test was performed to determine the hydraulic conductivity of the PRBs. The PRB reactors were operated as up flow. For all the PRB columns, constant flow rate of $0.483 \mathrm{~mL} / \mathrm{min}$ was maintained by using a peristaltic pump. Average hydraulic residence times for PRB-1, PRB-2, and PRB-3 were 36.57, 40.37, and 39.68 h, respectively. Hy- 
draulic testes resulted in similar values for porosity, pore volume, hydraulic conductivity, and hydraulic residence times for the three PRB reactors.

Table 5. Hydraulic parameters for PRBs.

\begin{tabular}{cccc}
\hline & PRB-1 & PRB-2 & PRB-3 \\
\hline Reactor volume $(\mathrm{mL})$ & 4710 & 4710 & 4710 \\
Pore volume $(\mathrm{mL})$ & 1060 & 1170 & 1150 \\
Hydraulic conductivity $(\mathrm{cm} / \mathrm{s})$ & 0.779 & 0.729 & 0.766 \\
Porosity $(\%)$ & 0.225 & 0.248 & 0.244 \\
Flow rate $(\mathrm{mL} / \mathrm{min})$ & 0.483 & 0.483 & 0.483 \\
Hydraulic residence time $(\mathrm{h})$ & 36.57 & 40.37 & 39.68 \\
\hline
\end{tabular}

\subsection{Toluene Removal Rates}

Consecutive toluene bioremediation studies were performed for influent concentrations of $5 \mathrm{mg} / \mathrm{L}$ (phase 1), $15 \mathrm{mg} / \mathrm{L}$ (phase 2) and $25 \mathrm{mg} / \mathrm{L}$ (phase 3) for the PRB columns.

Results of phase 1: In phase 1, toluene concentration in the influent tank for three PRB reactors was prepared as $5 \mathrm{mg} / \mathrm{L}$. Toluene removal rates for $5 \mathrm{mg} / \mathrm{L}$ influent are depicted in Figure 2. After 44 days of treatment, toluene concentrations were decreased from 5 to $4.29 \mathrm{mg} / \mathrm{L}$ (greater than the threshold value of $0.7 \mathrm{mg} / \mathrm{L}$ set by World Health Organization) by the natural attenuation treatment (PRB-3) process, which represents a $14.2 \%$ removal efficiency. In PRB-1, toluene was reduced from 5 to $0.59 \mathrm{mg} / \mathrm{L}$ (less than the threshold value of $0.7 \mathrm{mg} / \mathrm{L}$ ), which represents a removal efficiency of $88.2 \%$. In PRB-2, toluene was reduced from 5 to $0.1 \mathrm{mg} / \mathrm{L}$ (less than the threshold value of $0.7 \mathrm{mg} / \mathrm{L}$ ), which represents a removal efficiency of $98 \%$.

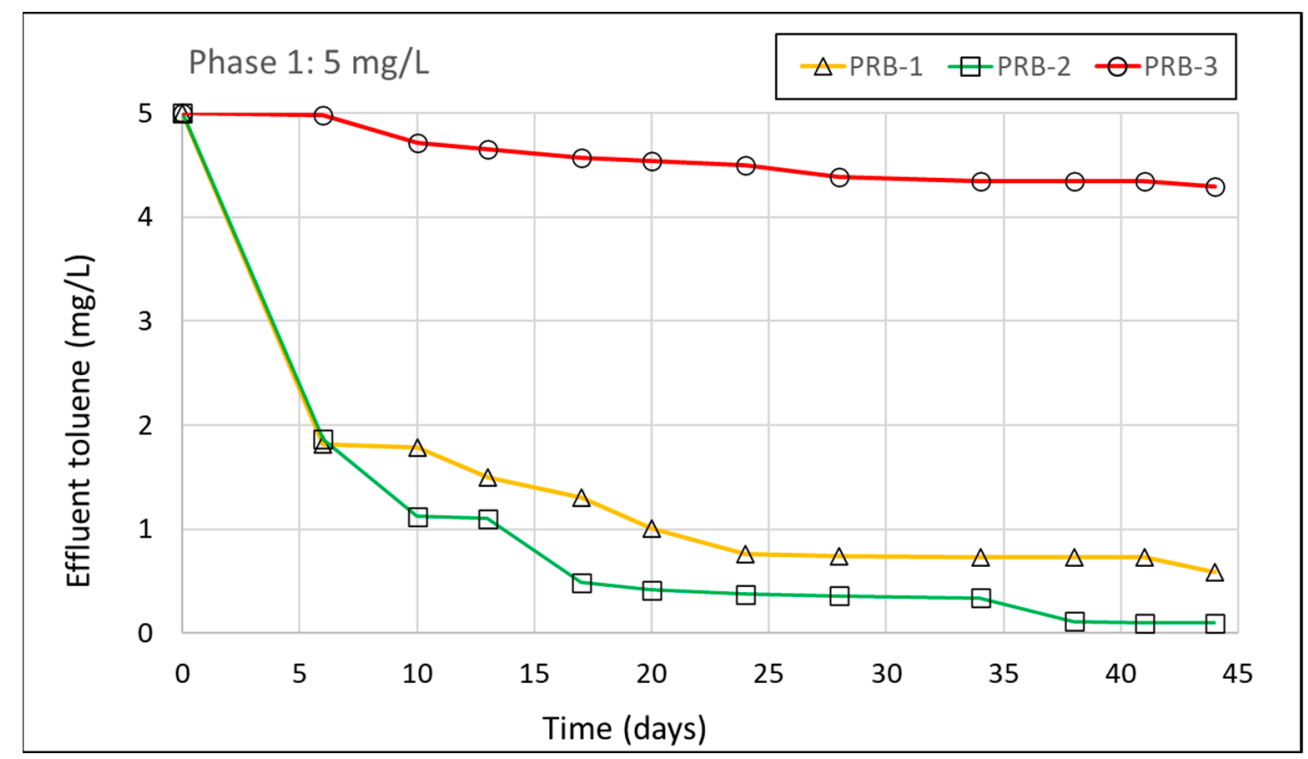

Figure 2. Changes in toluene concentrations in the PRB columns for phase 1.

Results of phase 2: In phase 2, toluene concentration in the influent tank for three PRB reactors was prepared as $15 \mathrm{mg} / \mathrm{L}$. Toluene removal rates for $15 \mathrm{mg} / \mathrm{L}$ influent are depicted in Figure 3. After 64 days of treatment, toluene concentrations were decreased from 15 to $5.47 \mathrm{mg} / \mathrm{L}$ (greater than the threshold value of $0.7 \mathrm{mg} / \mathrm{L}$ set by WHO) by the natural attenuation treatment (PRB-3) process, which represents a $63.5 \%$ removal efficiency. In PRB-1, toluene was reduced from 15 to $1.25 \mathrm{mg} / \mathrm{L}$ (greater than the threshold value of $0.7 \mathrm{mg} / \mathrm{L}$ ), which represents a removal efficiency of $91.7 \%$. In PRB-2, toluene was reduced from 15 to $0.1 \mathrm{mg} / \mathrm{L}$ (less than the threshold value of $0.7 \mathrm{mg} / \mathrm{L}$ ), which represents a removal efficiency of $99.3 \%$. 


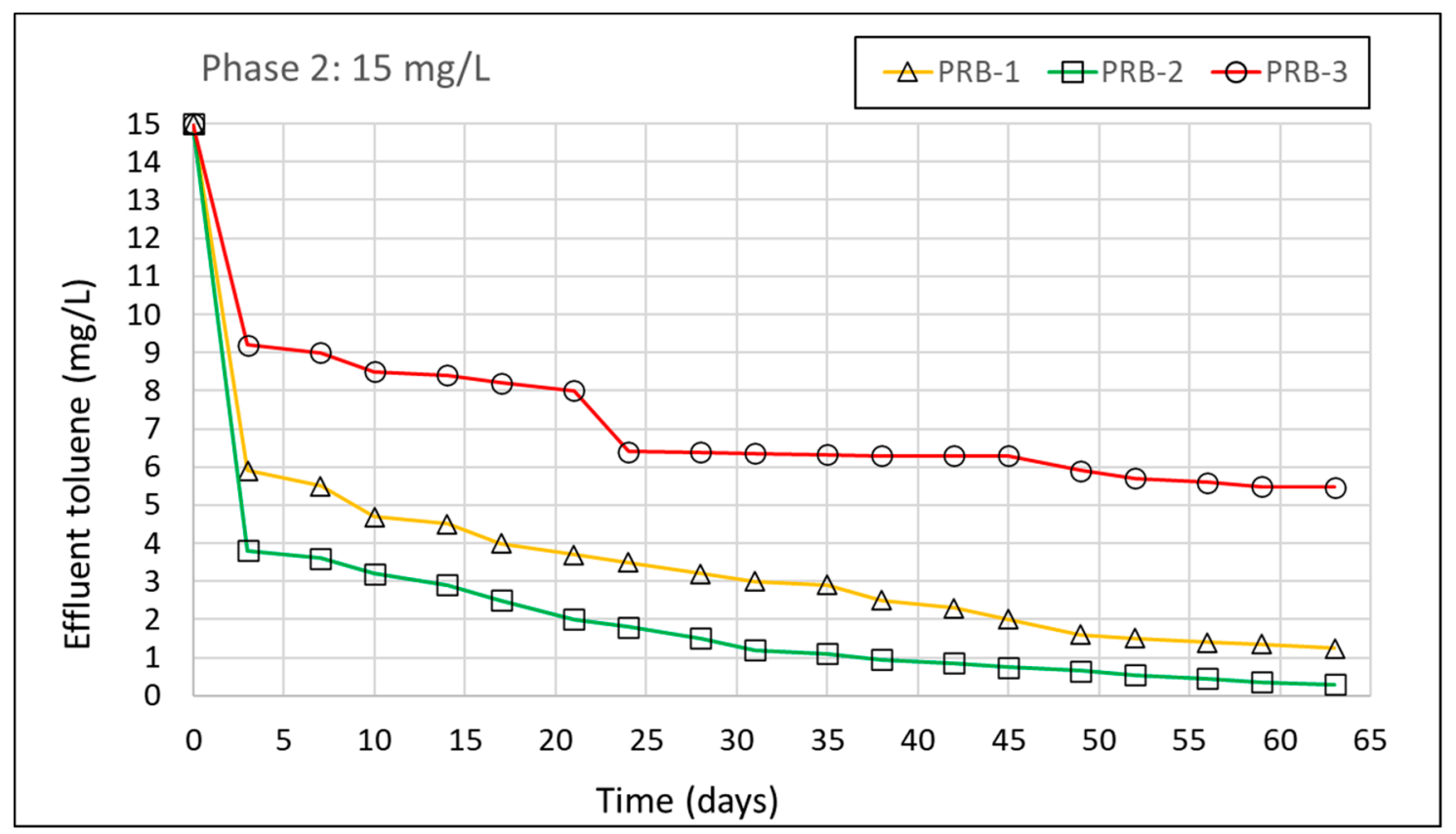

Figure 3. Changes in toluene concentrations in the PRB columns for phase 2.

Results of phase 3: In phase 3, toluene concentration in the influent tank for three PRB reactors was prepared as $25 \mathrm{mg} / \mathrm{L}$. Toluene removal rates for $25 \mathrm{mg} / \mathrm{L}$ influent are depicted in Figure 4. After 54 days of treatment, toluene concentrations were decreased from 25 to $7.85 \mathrm{mg} / \mathrm{L}$ (greater than the threshold value of $0.7 \mathrm{mg} / \mathrm{L}$ set by WHO) by the natural attenuation treatment (PRB-3) process, which represents a $68.6 \%$ removal efficiency. In PRB-1, toluene was reduced from 25 to $1.54 \mathrm{mg} / \mathrm{L}$ (greater than the threshold value of $0.7 \mathrm{mg} / \mathrm{L}$ ), which represents a removal efficiency of $93.8 \%$. In PRB-2, toluene was reduced from 25 to $0.465 \mathrm{mg} / \mathrm{L}$ (less than the threshold value of $0.7 \mathrm{mg} / \mathrm{L}$ ), which represents a removal efficiency of $98.1 \%$.

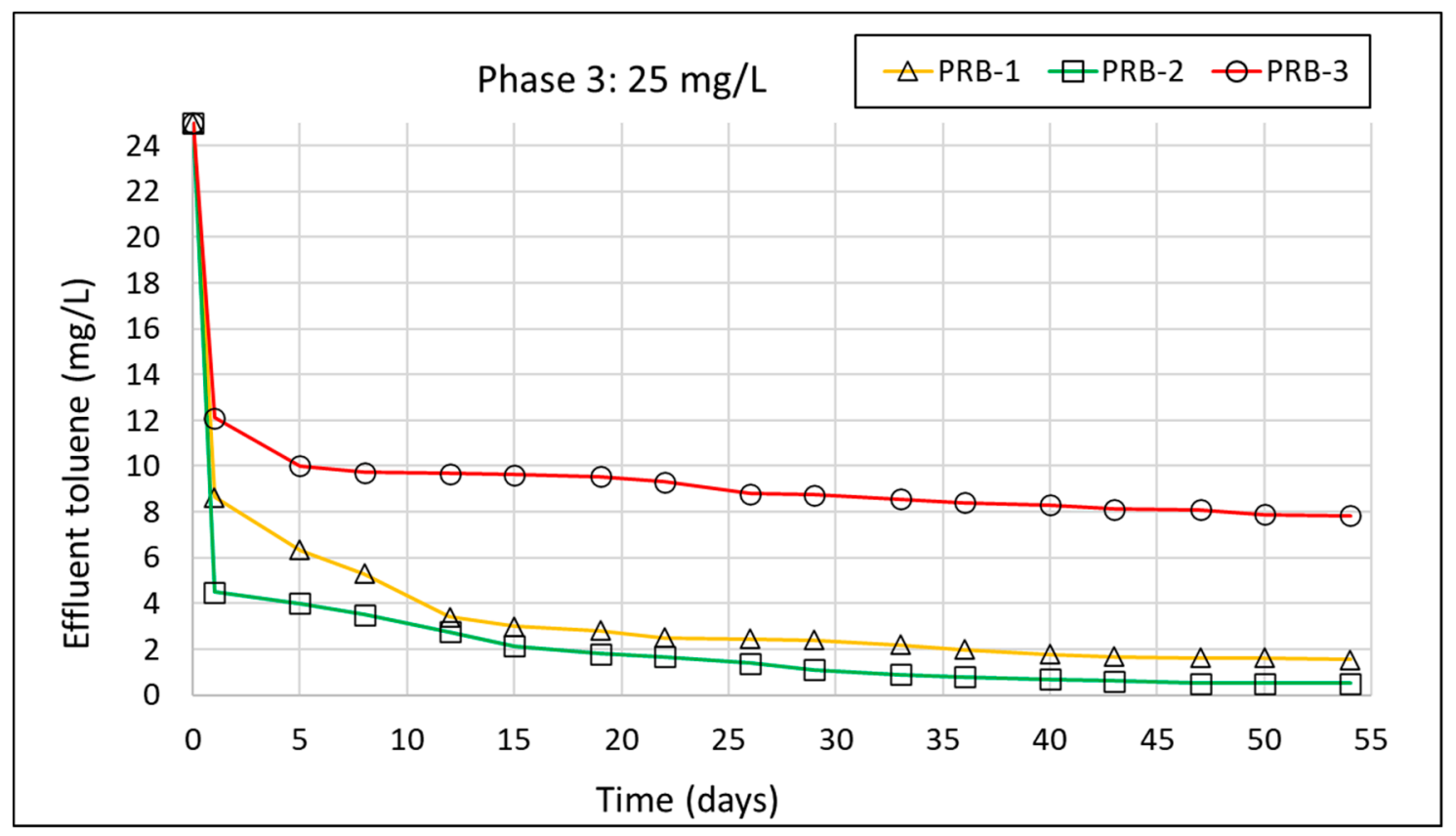

Figure 4. Changes in toluene concentrations in the PRB columns for phase 3. 
Figure 5 shows the toluene removal rates in PRB-2 for phase 1, phase 2, and phase 3 combined. Regardless of the influent concentration, final toluene removal rates in PRB-2 for phase 1, phase 2, and phase 3 were always greater than $97 \%$. Additionally, the final toluene concentrations in PRB-2 were always less than the threshold value of $0.7 \mathrm{mg} / \mathrm{L}$ set by WHO.

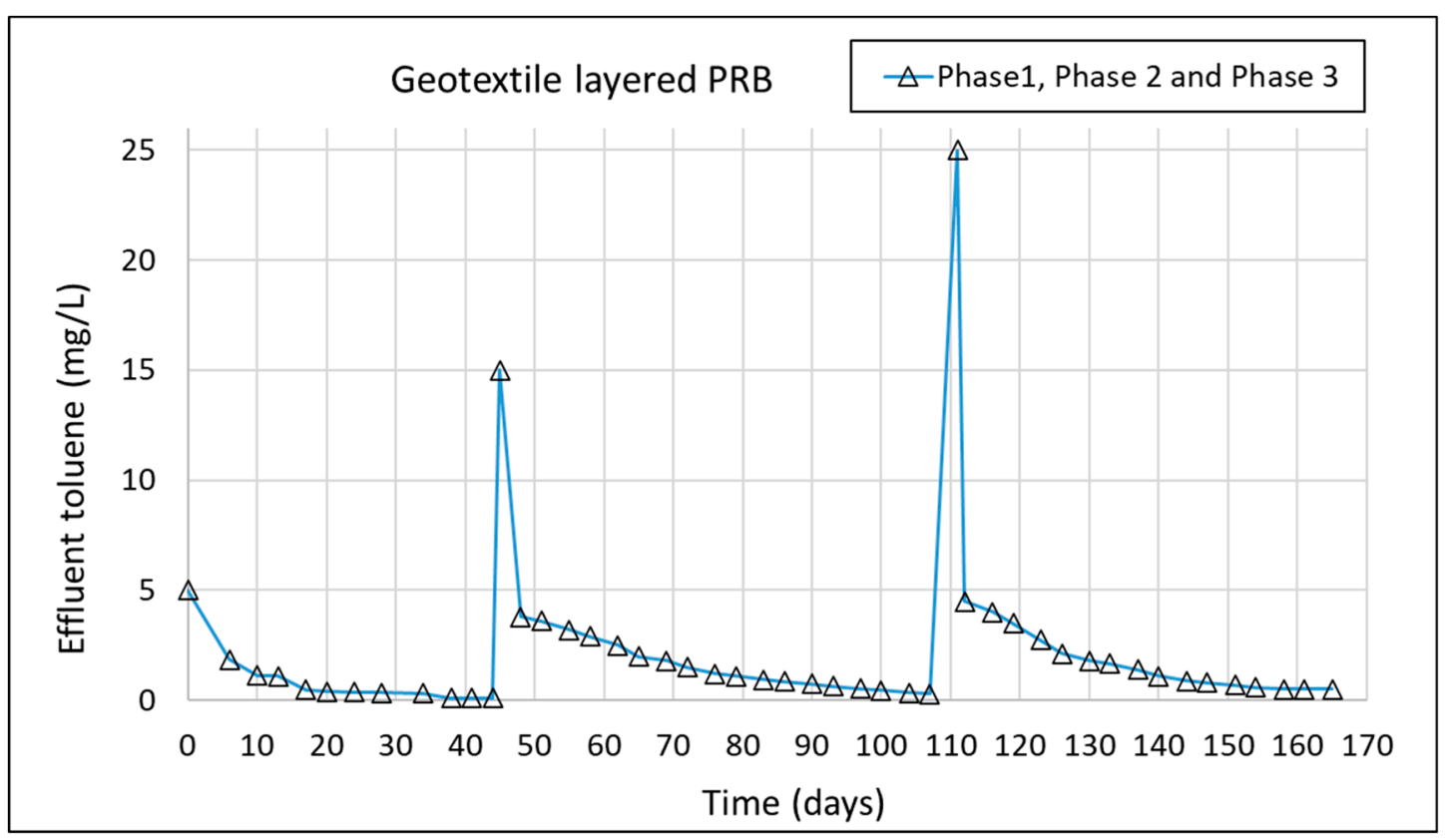

Figure 5. Changes in toluene concentrations in the PRB-2 column for phase 1, phase 2, and phase 3 combined.

\subsection{Conductivity, $p H$, and DO Results (All Phases Combined)}

In this study, conductivity, $\mathrm{pH}$, and dissolved oxygen values in the PRB effluents were monitored twice a week. Conductivity readings for the three PRB columns were presented in Figure 6. Conductivity reading values were recorded between 26 and $81.9 \mu \mathrm{S} / \mathrm{cm}$ for PRB-3, which indicated steadiness compared to PRB-1 and PRB-2. However, PRB-1 and PRB-2 showed higher conductivity readings due to the addition of weekly nutrients and monthly microbial inoculum. Conductivity values in the effluents of PRB-1 and PRB-2 varied between 46.9 and $500 \mu \mathrm{S} / \mathrm{cm}$, which indicated more fluctuations in the conductivity values compared to PRB-3. It can be seen in Figure 7 that the effluent $\mathrm{pH}$ values for the three PRBs started at near-neutral, then for PRB-1 and PRB-2 it remained between 6.1 and 8.3, whereas for PRB-3 the range was between 7.4 and 9.29. The DO values were maintained always greater than $3 \mathrm{mg} / \mathrm{L}$ by intermittent aeration of the influent tanks of PRB-1 and PRB-2 (Figure 8).

\subsection{Bioremediation Kinetics}

The data obtained from the toluene bioremediation were applied to the first-order rate model. Figures 9-11 show fits of the first-order kinetic model to data from the PRB-1, PRB-2, and PRB-3 treatment processes for phase 1, phase 2 and phase 3 studies. It is clearly seen from the figures that the first-order reaction rate model is validated by the $\mathrm{R}^{2}$ values. The reaction rate coefficient $(\mathrm{k})$, reaction order $(\mathrm{n})$ and half-reaction time $\left(t_{1 / 2}\right)$ were determined from the curves in the figures and are summarized in Table 6 for each treatment process. 


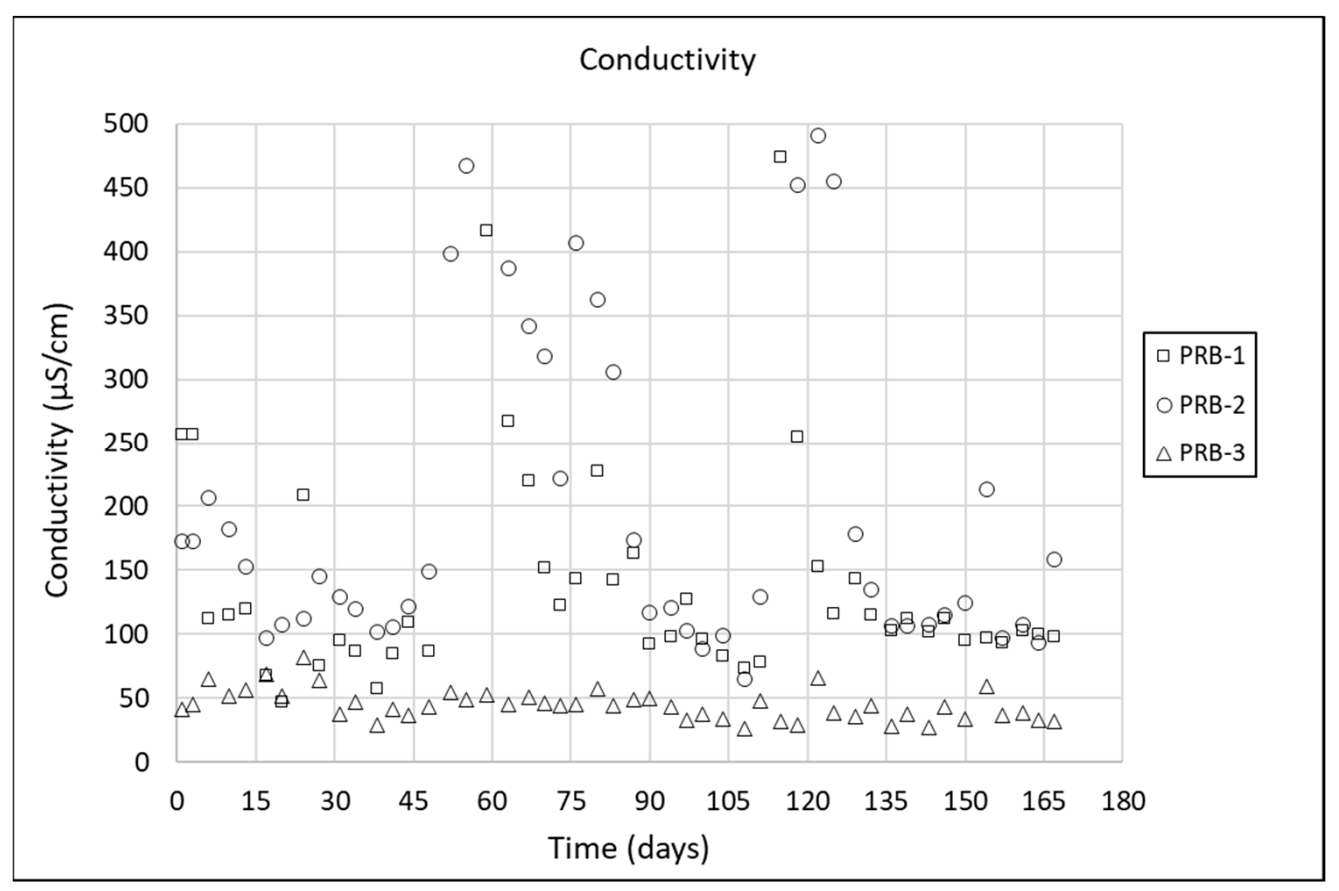

Figure 6. Changes in conductivity in PRB column reactors.

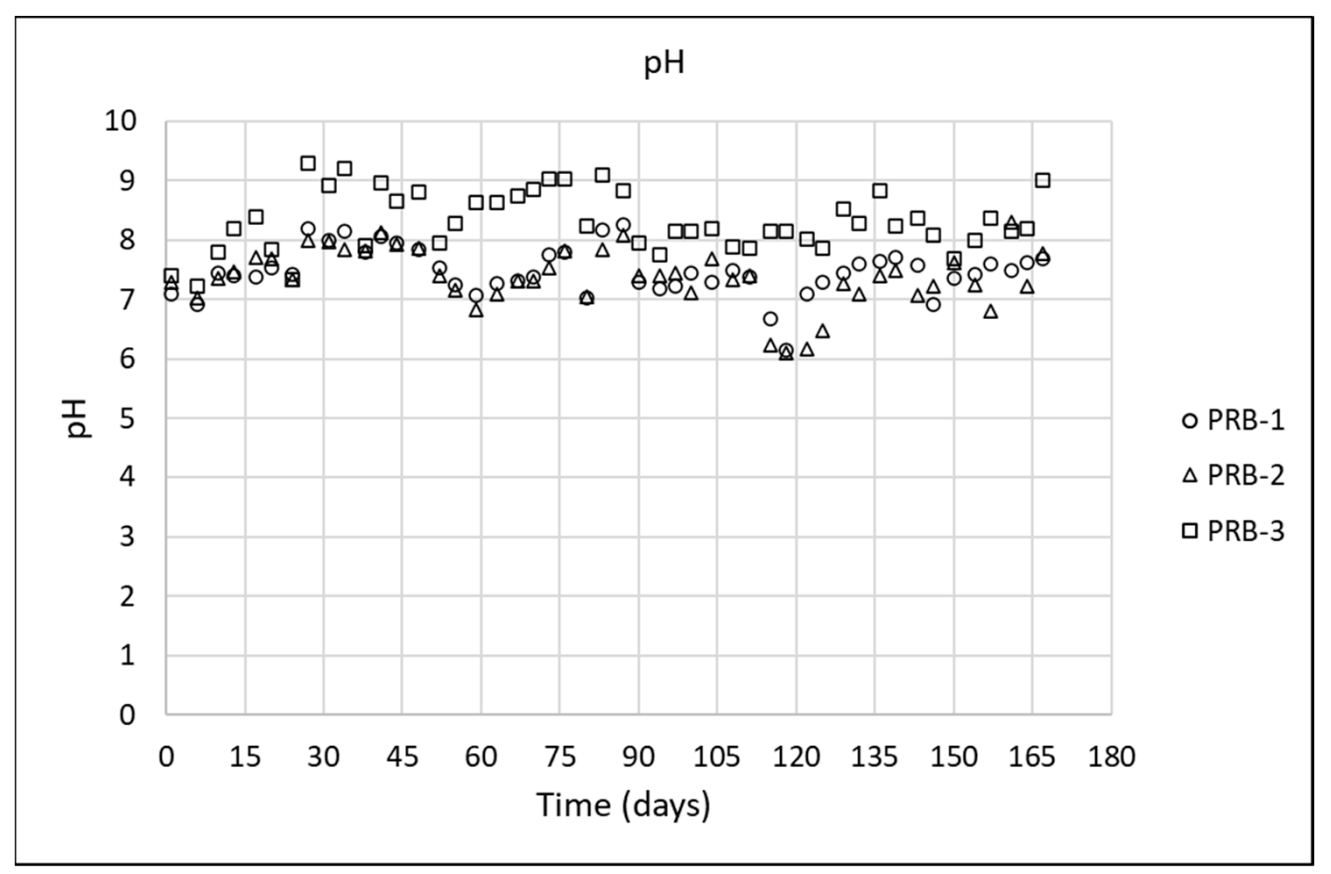

Figure 7. Changes in $\mathrm{pH}$ in $\mathrm{PRB}$ column reactors. 


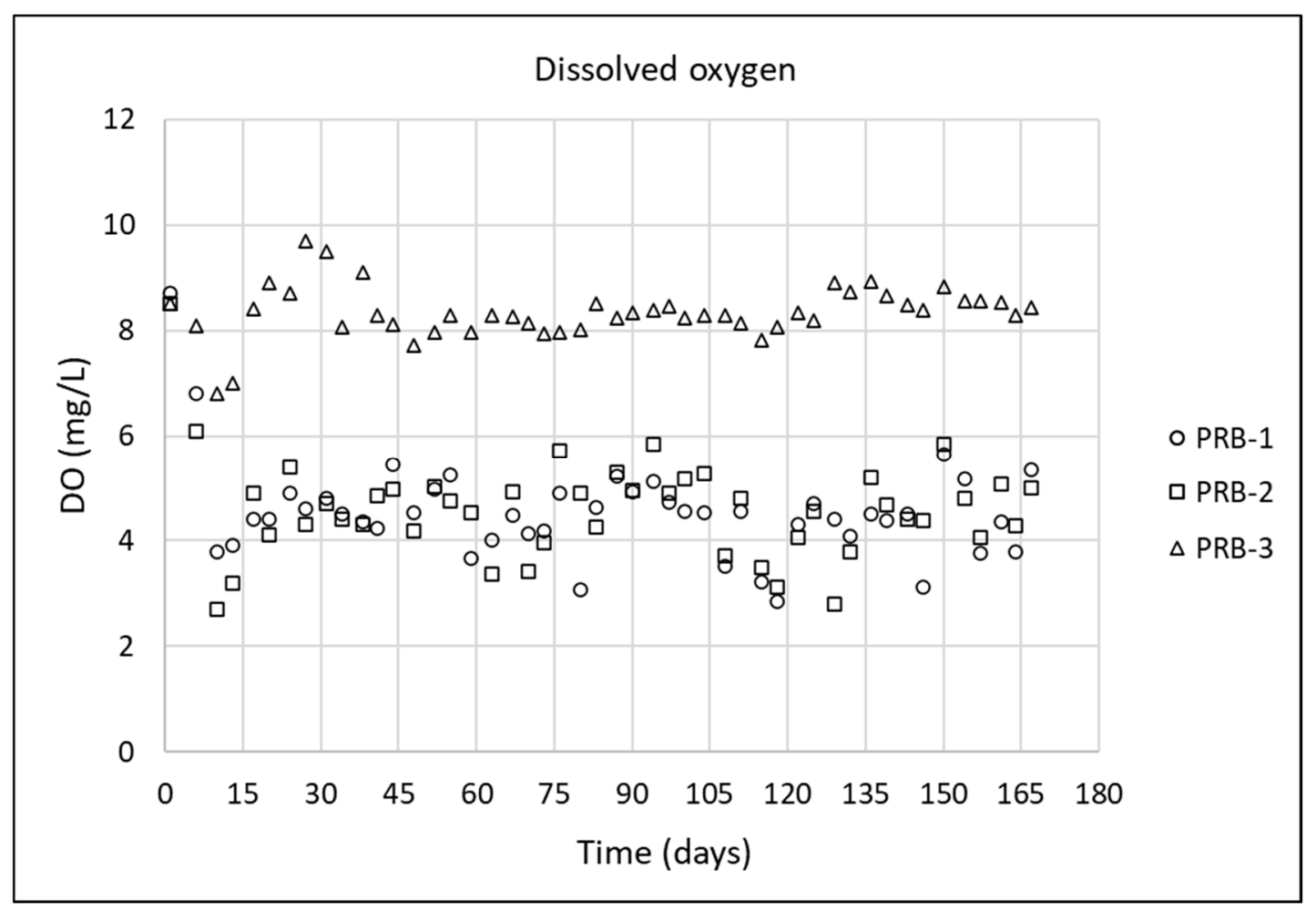

Figure 8. Changes in dissolved oxygen in PRB column reactors.

PRB $1(B A+B S)$

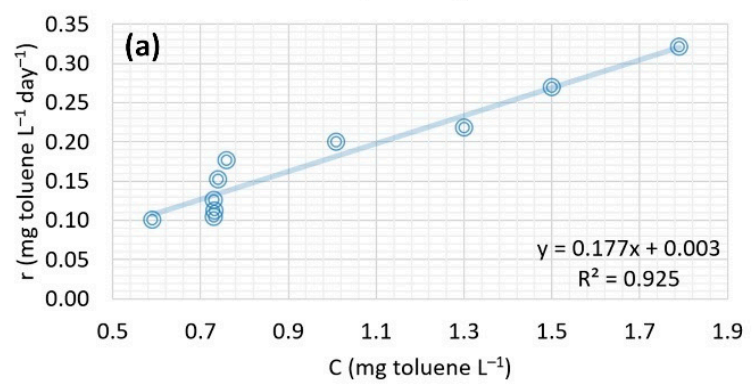

$\mathrm{PRB} 2(\mathrm{BA}+\mathrm{BS}+\mathrm{GT})$

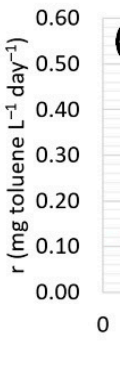

(b)

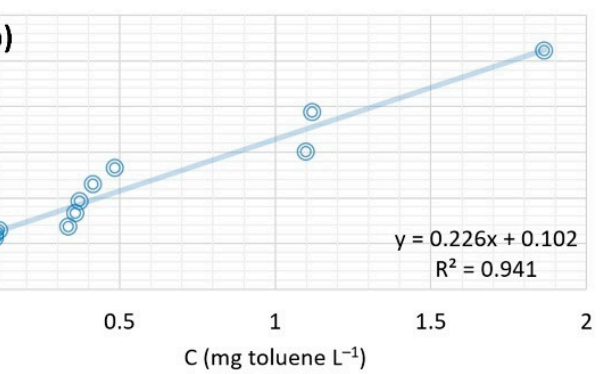

PRB 3 (NA)

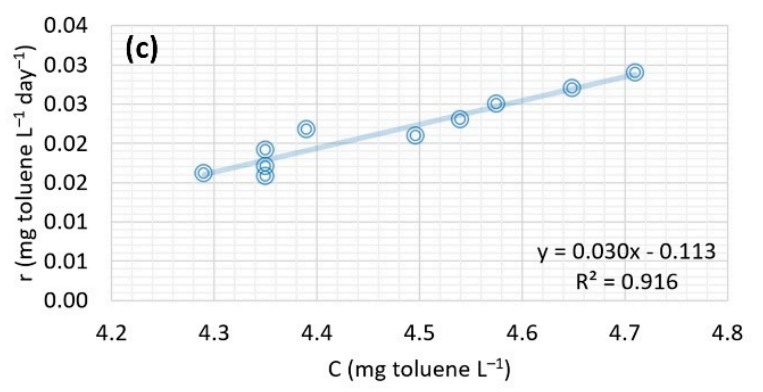

Figure 9. Reaction rate data for the PRB toluene treatment processes for phase 1: (a) The first-order model for PRB-1, (b) the first-order model for PRB-2, and (c) the first-order model for PRB-3. 
PRB 1 (BA + BS)

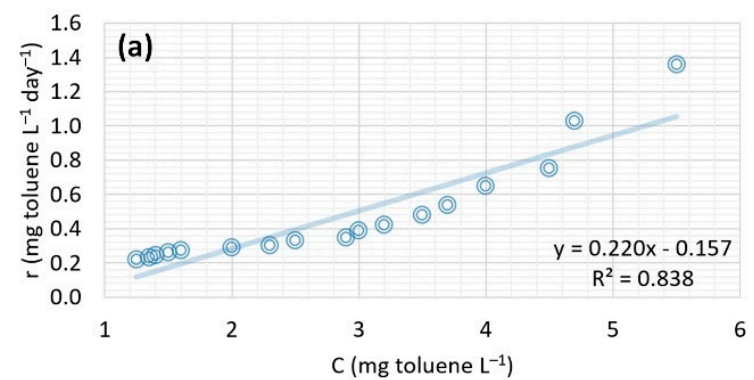

PRB $2(B A+B S+G T)$

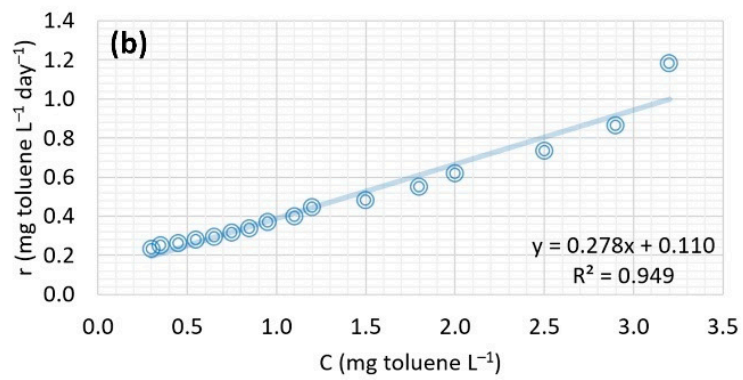

PRB 3 (NA)

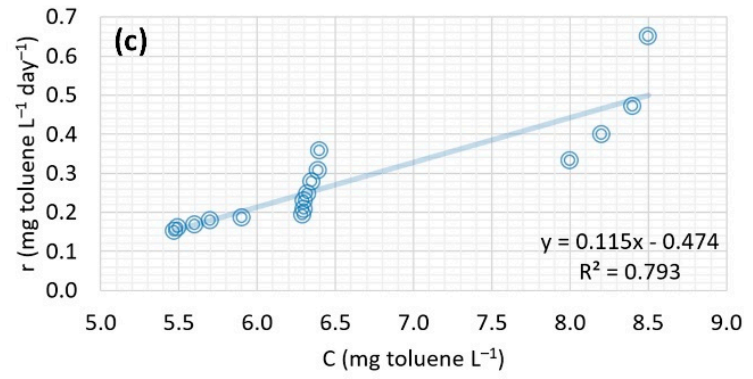

Figure 10. Reaction rate data for the PRB toluene treatment processes for phase 2: (a) The first-order model for PRB-1, (b) the first-order model for PRB-2, and (c) the first-order model for PRB-3.
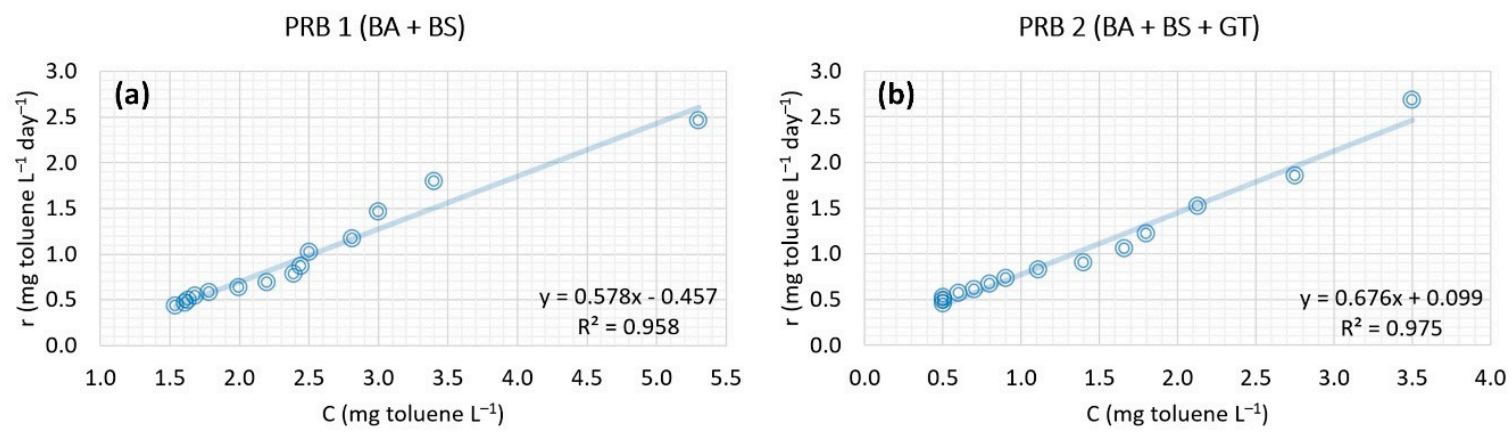

PRB 3 (NA)

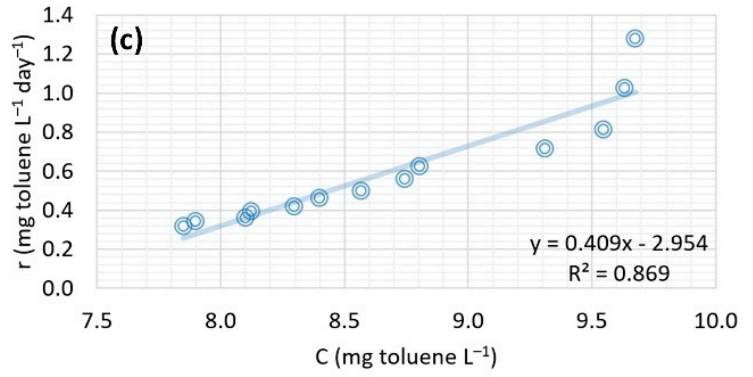

Figure 11. Reaction rate data for the PRB toluene treatment processes for phase 3: (a) The first-order model for PRB-1, (b) the first-order model for PRB-2, and (c) the first-order model for PRB-3. 
Table 6. Calculated reaction rate factors for the first-order kinetic model.

\begin{tabular}{|c|c|c|c|}
\hline & PRB-1 & PRB-2 & PRB-3 \\
\hline \multirow{4}{*}{ Phase 1} & $\mathrm{k}: 0.18 \mathrm{~d}^{-1}$ & $\mathrm{k}: 0.23 \mathrm{~d}^{-1}$ & $\mathrm{k}: 0.03 \mathrm{~d}^{-1}$ \\
\hline & $t_{1 / 2}: 3.91 \mathrm{~d}$ & $t_{1 / 2}: 3.06 \mathrm{~d}$ & $t_{1 / 2}: 22.95 \mathrm{~d}$ \\
\hline & $n=1$ & $n=1$ & $n=1$ \\
\hline & $\mathrm{R}^{2}: 0.93$ & $\mathrm{R}^{2}: 0.94$ & $\mathrm{R}^{2}: 0.92$ \\
\hline \multirow{4}{*}{ Phase 2} & $\mathrm{k}: 0.22 \mathrm{~d}^{-1}$ & $\mathrm{k}: 0.28 \mathrm{~d}^{-1}$ & $\mathrm{k}: 0.11 \mathrm{~d}^{-1}$ \\
\hline & $t_{1 / 2}: 3.14 \mathrm{~d}$ & $t_{1 / 2}: 2.49 \mathrm{~d}$ & $t_{1 / 2}: 6.04 \mathrm{~d}$ \\
\hline & $n=1$ & $n=1$ & $n=1$ \\
\hline & $\mathrm{R}^{2}: 0.84$ & $\mathrm{R}^{2}: 0.95$ & $\mathrm{R}^{2}: 0.79$ \\
\hline \multirow{4}{*}{ Phase 3} & $\mathrm{k}: 0.58 \mathrm{~d}^{-1}$ & $\mathrm{k}: 0.68 \mathrm{~d}^{-1}$ & $\mathrm{k}: 0.41 \mathrm{~d}^{-1}$ \\
\hline & $t_{1 / 2}: 1.19 \mathrm{~d}$ & $t_{1 / 2}: 1.02 \mathrm{~d}$ & $t_{1 / 2}: 1.69 \mathrm{~d}$ \\
\hline & $n=1$ & $n=1$ & $n=1$ \\
\hline & $\mathrm{R}^{2}: 0.96$ & $\mathrm{R}^{2}: 0.97$ & $\mathrm{R}^{2}: 0.87$ \\
\hline
\end{tabular}

\section{Discussion}

Hydraulic conductivity is a property of the porous media. It depends on the pore size, its distribution, and its connectivity. The hydraulic conductivity depends on the size of the pores, their spatial distribution and connection properties. In most cases, hydraulic conductivity decreases as the change in pore size increases. Hydraulic tests showed similar values for porosity, pore volume, hydraulic conductivity, and hydraulic residence times for the three PRB columns.

The influent was introduced from the bottom of the PRB reactors in each phase. The influent samples for PRB-1 and PRB-2 were exactly the same, which included the addition of essential nutrients and bacterial inoculum. PRB-3 was operated as control under natural attenuation conditions without adding nutrients and microorganisms. Since oxygen and nutrients are essential for toluene biodegradation, lower removal rates in PRB-3 were expected. Intermittent aeration was performed in the PRB-1 and PRB-2 influent tank when the DO levels fell below $3 \mathrm{mg} / \mathrm{L}$. In addition to intermittent aeration, nutrients and bacterial inoculum were added to the influent tank of PRB-1 and PRB-2 at the doses presented in Section 2.6. Unlike PRB-1 and PRB-3, PRB-2 included 12 layers of nonwoven geotextile fabrics horizontally placed at $5 \mathrm{~cm}$ intervals. The reason for using nonwoven geotextile fabrics was to benefit from its biomass holding capacity, as reported in the literature [18]. The efficiency of toluene biodegradation was the highest when the BS and BA processes were combined in PRB-1 and PRB-2. Owing to its 12 layers of nonwoven geotextile fabric, PRB-2 displaced higher toluene removal rates than PRB-1 and PRB-3. Furthermore, intermittent aeration, bacterial inoculation, and nutrient addition were performed for PRB-1 and PRB-2. The effluent toluene concentrations in all phases for PRB-2 were less than the guideline value $(0.7 \mathrm{mg} / \mathrm{L})$ of the water for human consumption, as suggested by the World Health Organization [25]. Effluent toluene concentrations in PRB-1 exceeded the WHO's guideline value of $0.7 \mathrm{mg} / \mathrm{L}$ in phase 2 and phase 3 , and PRB- 3 exceeded the WHO's guideline value of $0.7 \mathrm{mg} / \mathrm{L}$ in all phases.

Conductivity of effluent samples is used as an indicator of dissolved inorganic species or total ion concentration and is a measure of the solution's ability to conduct an electric current. Conductivity readings for PRB-3 did not change much during the course of the study; however, PRB-1 and PRB-2 yielded higher conductivity readings due to the addition of weekly nutrients and monthly microbial inoculum. Results of this study indicated that the average $\mathrm{pH}$ value of the three PRB treatment columns varied from 6.1 to 9.29. A $\mathrm{pH}$ value between 6.7 and 9.0 enhances the microbial activity during biodegradation [26]. Oxygen is an important parameter in toluene biodegradation because it not only acts as the terminal electron acceptor for respiration, but also takes part in the initial enzymatic activation of toluene. The main feature of aerobic biodegradation of toluene is the initial "activation" of the aromatic ring with the addition of the oxygen element. Several such additions lead to carboxylic acids or substituted pyrocatechols [27]. Carboxylic acids and 
pyrocatechols can then be converted to tricarboxylic acid cycle (TCA cycle) intermediates through ring cleavage, and the TCA cycle completely oxidized intermediates to $\mathrm{CO}_{2}$ and $\mathrm{H}_{2} \mathrm{O}$ [28]. In toluene bioremediation, biostimulation is widely used to stimulate the growth of existing microorganisms by providing adequate $\mathrm{DO}$ and nutrients [29]. In a contaminated aquifer, due to the redox gradient along the groundwater flow direction, if the aquifer contains significant amount of dissolved oxygen (DO), oxygen is usually found in low concentration at the edge of the contaminant cloud. The content of the individual nutrients in the influent water must correspond to the needs of the bacteria in the PRB columns (PRB-1 and PRB-2) and have a balanced relationship between C, N, and P. This is crucial to the efficiency of biological degradation processes. The amount of nutrients to be added to PRB-1 and PRB-2 influent tanks was determined based on the selected C:N:P ratio of 100:5:1. Carbon is the principal component of toluene that microorganisms use to build their cell structures and to generate energy. Nutrients are essential for the growth of bacteria that play an important role in the degradation of toluene. For instance, nitrogen, which is one of the essential nutrients, is part of the structure of protein, DNA, RNA, and ATP. Phosphorous is the other important nutrient for microbial growth. Phosphorous is an important player in making nucleic acids and cellular energy transfers.

It has been reported in the literature that the first-order kinetic model can be used for petroleum-hydrocarbon biodegradation [23,30-32]. The coefficients calculated from the first-order kinetics model in phase $3(25 \mathrm{mg} / \mathrm{L})$ clearly showed that the model fits better for PRB-1 and PRB-2 than PRB-1 based on $\mathrm{R}^{2}$ values. However, in phase $1(5 \mathrm{mg} / \mathrm{L})$, the kinetic model fits better for all PRBs. In phase $2(15 \mathrm{mg} / \mathrm{L})$, the kinetic model fits better for PRB-2 and PRB-3. For instance, the first-order reaction rate (k) in the PRB-2 process was higher compared to PRB-1 and PRB-3 in three phases. The half-reaction time $\left(t_{1 / 2}\right)$ determined from the reaction rate $(\mathrm{k})$ in PRB-2 process was thus smaller than in PRB-1 and PRB-3. As the influent toluene concentration for each PRB column increased from 5 to $15 \mathrm{mg} / \mathrm{L}$, then to $25 \mathrm{mg} / \mathrm{L}$, half-lives $\left(t_{1 / 2}\right)$ decreased, and reaction rates $(\mathrm{k})$ increased.

A suggestion for further research is to study a full life cycle assessment (LCA) and investigate the mitigation of greenhouse gas (GHG) emissions resulting from toluene contamination in the subsurface environment. There have been recent studies on mitigating GHG emissions resulting from waste treatment activities [33,34]. Similar studies can be performed to evaluate GHG emissions from petroleum contamination in the subsurface environment.

\section{Conclusions}

The persistence of toluene in groundwater long after initial contamination, coupled with the costly treatment methods available, have made toluene an environmental pollutant of concern. This lab-scale study assessed a potential PRB configuration suitable for the remediation of sites containing toluene contamination. It was also the first reported use of geotextile fabrics in a PRB configuration. The geotextile fabrics in PRB-2 achieved a greater toluene removal capacity than the other PRB designs. The results suggest that this PRB configuration might be appropriate for the treatment of groundwater sites that are contaminated with toluene. However, further field studies would help predict the life of this PRB under the dynamic and extreme conditions. Geotextile layered PRBs containing a sand and gravel mixture seem to be a promising bioremediation technology for contaminated groundwater with toluene. For field application; however, further research is needed to address problems such as higher concentrations of toluene (greater than $25 \mathrm{mg} / \mathrm{L}$ ). The hypothesis is that, by using geotextile layered PRBs, high-cost savings are expected compared to today's technologies, such as pump-and-treat methods. The next step of this study is to find out bacterial distribution, specifically toluene-degrading bacteria, from 12 geotextile fabric specimens and the sand-gravel mixture by using $16 \mathrm{~S}$ next-generation sequencing (NGS) metagenome analysis.

Author Contributions: Conceptualization, C.Y and A.B.Y.; methodology, C.Y., I.A., S.R., A.Q. and M.B.; validation, O.A.; resources, N.I.B.; data curation, C.Y and A.B.Y.; writing-original draft 
preparation, C.Y.; writing-review and editing, E.C.; visualization, S.T.G.; supervision, O.A. All authors have read and agreed to the published version of the manuscript.

Funding: This research was funded by Imam Abdulrahman bin Faisal University (IAU) project No. (2019-037-Eng) throughout the Deanship of Scientific Research (DSR).

Institutional Review Board Statement: Not applicable.

Informed Consent Statement: Not applicable.

Data Availability Statement: Not applicable.

Acknowledgments: The authors would like to thank Abdulrahman bin Faisal University for academic support and Megan Kramer Jaunich for proofreading the manuscript.

Conflicts of Interest: The authors declare no conflict of interest.

\section{References}

1. Thiruvenkatachari, R.; Vigneswaran, S.; Naidu, R. Permeable reactive barrier for groundwater remediation. J. Ind. Eng. Chem. 2008, 14, 145-156. [CrossRef]

2. Upadhyay, S.; Sinha, A. Role of Microorganisms in Permeable Reactive Bio-Barriers (PRBBs) for Environmental Clean-Up: A Review. Glob. NEST J. 2018, 20, 269-280. [CrossRef]

3. Capodici, M.; Morici, C.; Viviani, G. Batch Test Evaluation of Four Organic Substrates Suitable for Biological Groundwater Denitrification. Chem. Eng. Trans. 2014, 38, 43-48. [CrossRef]

4. Liu, C.; Chen, X.; Mack, E.E.; Wang, S.; Du, W.; Yin, Y.; Banwart, S.A.; Guo, H. Evaluating a novel permeable reactive bio-barrier to remediate PAH-contaminated groundwater. J. Hazard. Mater. 2019, 368, 444-451. [CrossRef]

5. Fan, C.; Gao, Y.; Zhang, Y.; Dong, W.; Lai, M. Remediation of lead and cadmium from simulated groundwater in loess region in northwestern China using permeable reactive barrier filled with environmentally friendly mixed adsorbents. Environ. Sci. Pollut. Res. 2018, 25, 1486-1496. [CrossRef]

6. Frade, P.R.; Notini, L.; Santos, S.V.; Moreira, R.F.P.M.; Leão, M.M.D.; Amorim, C.C. Feasibility study of the use of basic oxygen furnace sludge in a permeable reactive barrier. J. Hazard. Mater. 2018, 351, 188-195. [CrossRef]

7. Jun, D.; Yongsheng, Z.; Weihong, Z.; Mei, H. Laboratory study on sequenced permeable reactive barrier remediation for landfill leachate-contaminated groundwater. J. Hazard. Mater. 2009, 161, 224-230. [CrossRef]

8. Zhou, D.; Li, Y.; Zhang, Y.; Zhang, C.; Li, X.; Chen, Z.; Huang, J.; Li, X.; Flores, G.; Kamon, M. Column test-based optimization of the permeable reactive barrier (PRB) technique for remediating groundwater contaminated by landfill leachates. J. Contam. Hydrol. 2014, 168, 1-16. [CrossRef]

9. Das, D.B.; Mirzaei, M. Dynamic effects in capillary pressure relationships for two-phase flow in porous media: Experiments and numerical analyses. AIChE J. 2012, 58, 3891-3903. [CrossRef]

10. Illangasekare, T.H.; Armbruster III, E.J.; Yates, D.N. Non-Aqueous-Phase Fluids in Heterogeneous Aquifers-Experimental Study. J. Environ. Eng. 1995, 121, 571-579. [CrossRef]

11. Teramoto, E.H.; Chang, H.K. A Screening Model to Predict Entrapped LNAPL Depletion. Water 2020, 12, 334. [CrossRef]

12. Chesnaux, R. Analytical closed-form solutions for assessing pumping cycles, times, and costs required for NAPL remediation. Environ. Geol. 2008, 55, 1381-1388. [CrossRef]

13. Johnston, C.D. Selecting and Assessing Strategies for Remediating LNAPL in Soils and Aquifers; CRC Care Pty Ltd.: Adelaide, Australia, 2010; Volume 18.

14. Iniesto, M.; Moreira, D.; Reboul, G.; Deschamps, P.; Benzerara, K.; Bertolino, P.; Saghaï, A.; Tavera, R.; López-García, P. Core microbial communities of lacustrine microbialites sampled along an alkalinity gradient. Environ. Microbiol. 2021, 23, 51-68. [CrossRef]

15. Liang, X.; Zhuang, J.; Löffler, F.E.; Zhang, Y.; DeBruyn, J.M.; Wilhelm, S.W.; Schaeffer, S.M.; Radosevich, M. Viral and bacterial community responses to stimulated Fe(III)-bioreduction during simulated subsurface bioremediation. Environ. Microbiol. 2019, 21, 2043-2055. [CrossRef] [PubMed]

16. Thompson, L.J.; Gray, V.; Lindsay, D.; Von Holy, A. Carbon:Nitrogen:Phosphorus ratios influence biofilm formation by Enterobacter cloacae and Citrobacter freundii. J. Appl. Microbiol. 2006, 101, 1105-1113. [CrossRef]

17. Bashaar, Y.A. Nutrients requirements in biological industrial wastewater treatment. Afr. J. Biotechnol. 2004, 3, 236-238. [CrossRef]

18. Yaman, C. Performance and Kinetics of Bioaugmentation, Biostimulation, and Natural Attenuation Processes for Bioremediation of Crude Oil-Contaminated Soils. Processes 2020, 8, 883. [CrossRef]

19. AlSalka, Y.; Karabet, F.; Hashem, S. Development and optimisation of quantitative analytical method to determine BTEX in environmental water samples using HPLC-DAD. Anal. Methods 2010, 2, 1026. [CrossRef]

20. Bahrami, A.; Mahjub, H.; Sadeghian, M.; Golbabaei, F. Determination of Benzene, Toluene and Xylene (BTX) Concentrations in Air Using HPLC Developed Method Compared to Gas Chromatography. Int. J. Occup. Hyg. 1970, 3, $12-17$.

21. Yusiasih, R.; Marvalosha, R.; Suci, S.D.S.; Yuliani, E.; Pitoi, M.M. Low volume liquid-liquid extraction for the determination of benzene, toluene, and xylene in water by GC-FID and HPLC-UV. IOP Conf. Ser. Earth Environ. Sci. 2019, 277, 012019. [CrossRef] 
22. Komilis, D.P.; Vrohidou, A.-E.K.; Voudrias, E.A. Kinetics of Aerobic Bioremediation of a Diesel-Contaminated Sandy Soil: Effect of Nitrogen Addition. Water Air Soil Pollut. 2010, 208, 193-208. [CrossRef]

23. Chemlal, R.; Tassist, A.; Drouiche, M.; Lounici, H.; Drouiche, N.; Mameri, N. Microbiological aspects study of bioremediation of diesel-contaminated soils by biopile technique. Int. Biodeterior. Biodegrad. 2012, 75, 201-206. [CrossRef]

24. Tellez, G.T.; Nirmalakhandan, N.; Gardea-Torresdey, J.L. Evaluation of biokinetic coefficients in degradation of oilfield produced water under varying salt concentrations. Water Res. 1995, 29, 1711-1718. [CrossRef]

25. WHO. Guidelines for Drinking-Water Quality; World Health Organization: Geneva, Switzerland, 2011.

26. Bernal, M.P.; Alburquerque, J.A.; Moral, R. Composting of animal manures and chemical criteria for compost maturity assessment. A review. Bioresour. Technol. 2009, 100, 5444-5453. [CrossRef] [PubMed]

27. Jindrová, E.; Chocová, M.; Demnerová, K.; Brenner, V. Bacterial aerobic degradation of benzene, toluene, ethylbenzene and xylene. Folia Microbiol. 2002, 47, 83-93. [CrossRef]

28. Madigan, M.T.; Martinko, J.M.; Parker, J. Brock Biology of Microorganisms, 9th ed.; Prentice Hall: Upper Saddle River, NJ, USA, 2000; ISBN 9780134261928.

29. Fernández Rodríguez, M.D.; García Gómez, M.C.; Alonso Blazquez, N.; Tarazona, J.V. Soil Pollution Remediation. In Encyclopedia of Toxicology; Wexler, P., Ed.; Academic Press Inc.: Oxford, UK, 2014; pp. 344-355. ISBN 9780123864550.

30. Brook, T.R.; Stiver, W.H.; Zytner, R.G. Biodegradation of Diesel Fuel in Soil Under Various Nitrogen Addition Regimes. Soil Sediment Contam. Int. J. 2001, 10, 539-553. [CrossRef]

31. Shewfelt, K.; Lee, H.; Zytner, R.G. Optimization of nitrogen for bioventing of gasoline contaminated soil. J. Environ. Eng. Sci. 2005, 4, 29-42. [CrossRef]

32. Rončević, S.; Dalmacija, B.; Ivančev-Tumbas, I.; Tričković, J.; Petrović, O.; Klašnja, M.; Agbaba, J. Kinetics of Degradation of Hydrocarbons in the Contaminated Soil Layer. Arch. Environ. Contam. Toxicol. 2005, 49, 27-36. [CrossRef] [PubMed]

33. Yaman, C. Investigation of greenhouse gas emissions and energy recovery potential from municipal solid waste management practices. Environ. Dev. 2020, 33, 100484. [CrossRef]

34. Korkut, N.E.; Yaman, C.; Küçükağa, Y. Greenhouse gas contribution of municipal solid waste collection: A case study in the city of Istanbul, Turkey. Waste Manag. Res. 2018, 36, 131-139. [CrossRef] 